\title{
Shabbetai Tsvis nedstigning til Farao - et jødisk eksempel på forløsning gennem urenhed
}

\author{
MARIANNE SCHLEICHER
}

\begin{abstract}
ENGLISH ABSTRACT: As a Jewish example of redemtion through impurity, this article analyses the 'strange acts' of the Jewish mystic Shabbetai Tsvi. These acts included pronunciation of the tetragrammaton, liturgical subversions of synagoge service and Jewish praxis in general, odd approaches to sex, praying at grave sites, extreme asceticism, and conversion to Islam. Referring to theories by Robert Bellah, Philippe Descola, and Hans J. Lundager Jensen, I argue for the adequacy of 'inverted dualism' as a concept that can explain these strange acts in conflict with Jewish law. The explanation is situated in the historical development of Israelite-Jewish religion from a monistic worldview, over a direct dualistic worldview, to an inverted, this-worldly dualism with great bearings on how Jews would perceive evil and the Torah.
\end{abstract}

DANSK RESUMÉ: Som et jødisk eksempel på forløsning gennem urenhed analyseres den jødiske mystiker Shabbetai Tsvis 'fremmedartede handlinger' så som udtalelse af tetragrammet, liturgiske omkalfatringer af synagogegudstjenesten og jødisk praksis generelt, mærkværdige tilgange til sex, grave som bedesteder, ekstrem askese og konversion til islam. Med reference til teorier af Robert Bellah, Philippe Descola og Hans J. Lundager Jensen argumenterer jeg for begrebet 'inverteret dualisme' som egnet til at forklare disse fremmedartede handlinger i konflikt med jødisk lovstof. Forklaringen indlejres i den israelitisk-jødiske religions udvikling fra en monistisk verdensopfattelse over en direkte dualistisk verdensopfattelse til en inverteret dualisme i det dennesides, hvilket især har konsekvens for opfattelsen af ondskab og Torah.

KEYWORDS: Shabbetai Tsvi; judaism; mysticism; heresy; inverted dualism; tantrism; immanentism

Shabbetai Tsvi (1626-1676) er kendt som en af jødedommens få kættere, der i det østlige middelhavsområde udførte og opfordrede til diverse fremmedartede handlinger i konflikt med traditionel jødisk praksis, herunder konversion til islam. Sammen med sin profet Nathan af Gaza formåede Shabbetai at samle en stor skare af tilhængere fra 
Ægypten i syd til Hamborg-Altona i nord, fra London i vest til Aleppo i øst, der med stor nærforventning knyttede håb til Shabbetai som Messias. Shabbetais konversion til islam afstedkom stort frafald, desillusion og forfølgelser af tidligere tilhængere, men en lille skare på ca. 2-300 familier fulgte i Shabbetais fodspor, etablerede Dönmeh-sekten i Salonika (nutidens Thessaloniki). "Dönmeh" betyder konvertit og refererer til, at disse familier officielt konverterede til islam. Indadtil holdt de imidlertid fast ved jødisk praksis og Shabbetais messiansk-mystiske form for jødedom. I forbindelse med den 1. Balkankrig (1912-1913) og den græsk-tyrkiske krig (1921-1922) immigrerede Dönmeh-sektens medlemmer til det, der stadig var Det Osmanniske Rige. Fra 1923 og frem var Dönmeh-sektens tilhængere stærke støtter af Mustafa Kemal Atatürks sekulære visioner for det nyudråbte Tyrkiet, hvor religion blev henvist til privatsfæren, som hele tiden havde været Dönmeh-sektens religiøse domæne. I slutningen af det 20. århundrede talte sekten ca. 15.000 medlemmer. Disse medlemmer lever i dag i og omkring Izmir (Liebes 1993, 95).

I dette temanummer af Religionsvidenskabeligt Tidsskrift om forløsning gennem urenhed har Shabbetais praksis og dens teologiske udlægning relevans, idet det eksemplificerer, hvad jeg vil kalde 'inverteret dualisme' som en fase i en analogistisk ontologis udvikling. Med begrebet 'inverteret dualisme' i forhold til analogistisk ontologis udvikling trækker jeg på elementer fra Robert Bellahs, Philippe Descolas og Hans J. Lundager Jensens tænkning om religions udvikling og varianter. Det drejer sig om Bellahs antagelse af, at den aksiale vending, der sætter ind i midten af det første årtusinde f.v.t., indebærer kulturernes gradvise udvikling fra monistiske til dualistiske livsanskuelser (Bellah 1963, 366-367). Livsanskuelser, også benævnt ontologier, foreligger i fire varianter ifølge Descola. Analogistisk ontologi vil typisk være opstået i takt med bystatskulturers fremkomst, hvor gradvis kompleksitetsforøgelse bl.a. har nødvendiggjort kategorisering. En sådan kategorisering af ontos, dvs. det værende, havde og har til formål at etablere overskueliggørende forbindelser, også kaldet analogier, mellem det værendes forskellige komponenter (Descola 2013, 202-205). Internt i den analogistiske ontologi har Lundager Jensen observeret, at der synes at være en udvikling fra monisme over dualisme til, hvad jeg her vil betragte som 'inverteret dualisme'. Lundager Jensen foreslår at se sådanne inversioner som beslægtede med indisk Tantrisme - hvorved tantrisme får en slags 'etic'-kvalitet som et generelt religionshistorisk fænomen, idet analogistisk ontologi udvikler sig i en retning, der ses både i indiske tantra-traditioner, især den asketiske kapalika-bevægelse, og i andre religiøse traditioner, hvor frelsen må gå gennem denne verdens urenhed, synd og død. Tankegangen bag forløsning gennem urenhed karakteriserer han også som miserabilisme. I alle tilfælde består inversionen i, at forløsning sker gennem en urenhed, der i monistiske og direkte dualistiske varianter af analogistisk ontologi var uforenelig med det hellige som kilde til velsignelse og frelse (Lundager Jensen 2017, 8). ${ }^{1}$

1 I forbindelse med forløbet "Israelitisk religion" i efteråret 2017 på grunduddannelsen på Religionsvidenskab, Aarhus Universitet introducerede Lundager Jensen idéen om ikke en, ikke to, men for så vidt tre faser $i$ en analogistisk ontologi. Faserne udspandt sig som følge af udviklingen fra en monistisk verdensopfattelse over en verdensforsagende dualisme til en dualisme, hvor frelsen søges i det dennesides. 


\section{Teologiske transformationer af synet på ondskab i israelitisk- jødisk religion}

For at illustrere udviklingen fra en monistisk verdensopfattelse over en direkte dualistisk verdensopfattelse til en inverteret dualisme i det dennesides vil jeg indledningsvis gennemgå den bibelske vending 'kom/gå til Farao' (bo' 'xl-par'oh) og dens reception i tidlig og middelalderlig jødedom. Vendingen optræder fire steder i den hebræiske bibel, nemlig Ex 6,11; 7,26; 9,1; 10,1, hvor især Exodus 10 udtrykker et monistisk syn på godt og ondt:

Gå til Farao, for jeg har forhærdet ham og hans hoffolk, for at jeg kan udføre disse tegn blandt dem, og for at du kan fortælle din søn og din sønnesøn om, hvordan egypterne fik min magt at føle, og om mine tegn, som jeg gjorde blandt dem, så I kan forstå, at jeg er Herren (Ex 10,1-3).

Forhærdelsen af Farao kommer til udtryk i Faraos onde handlinger, der umiddelbart begrunder, at Gud rammer Farao og hans folk med de ti plager. Faraos ondskab har imidlertid sin oprindelse i Gud, da den tjener som et didaktisk middel for Gud til at forklare israelitterne, hvad der sker, hvis man ikke husker sin gud og dennes indgriben på Israels Folks vegne.

I tidlig jødedom blev det i tiltagende grad svært at forsvare Guds retfærdighed i form af hans belønning af de loyale og hans straf over de glemsomme i dette liv. I stedet henviste man forventningen om, at retfærdigheden skulle ske fyldest, til en kommende tid, en kommende verden. Skellet mellem flere tidsaldre og flere verdener indvarsler en dualistisk livsanskuelse med konsekvens for tidens, kosmos' og menneskets beskaffenhed. De mest radikale eksempler findes i Dødehavsteksterne, hvor man kan læse, hvordan denne tidsalder skal afløses af en ny, hvordan denne verden står i kontrast til en himmelsk verden, og hvordan menneskeheden er opdelt i Lysets og Mørkets Sønner, analogt til Lysets og Mørkets Fyrste, der er prædestineret til at bekæmpe hinanden indædt (1QS 3,13-4,26). Da jødedommen er en monoteistisk religion, er det dog vigtigt at understrege, at dualismen kun kendetegner denne tidsalder, denne verden, da Guds almagt, også over ondskaben vil manifestere sig ved dommedag, hvor en ny og bedre monistisk orden vil etableres, hvor kun det gode vil eksistere. At ondskaben tilkendes et skær af selvstændig eksistens, er kun muligt i monoteistiske religioner, hvis ondskabens eksistens er tidsbegrænset og underordnet et guddommeligt formål. Der er selv i Dødehavsteksterne derfor kun tale om en dennesidig dualisme, som Gud har tilladt, for at de udvalgte motiveres til nu at søge frelsen i alt det, der konnoterer al hans transcendens.

Hvad angår vendingen 'Kom/gå til Farao', dukker den, så vidt jeg har kunnet konstatere, ikke direkte op i de tidligt jødiske tekster, fordi der ingen teologiske opfordringer er til at søge den kultur, som Farao repræsenterer i denne jordiske verden. Tværtimod transponeres Farao og det ægyptiske som repræsentanter for ondskab ind i Jubilæerbogen, hvor dæmonen Mastema beskrives som Moses' fjende, idet han hjælper Farao på samme vis som Gud hjælper Moses:

Og du [Moses] ved selv, ... hvad fyrst Mastema vilde gøre ved dig, da du vendte tilbage 
til Ægypten ... Han ønskede jo af al sin magt at dræbe dig og at fri Ægypterne ud af din hånd ... Og jeg friede dig ud af hans hånd (Jub 48,2-4).

Den antropologiske dualisme er her 'analogiseret', således at Mastema er Faraos beskytter, ligesom Jahve er Moses' beskytter. ${ }^{2}$ Hermed angives Mastema som ondskabens årsag, ligesom Jahve tænkes som det godes årsag, hvorfor kampen mod ondskaben er en nødvendighed. For en del jøder medførte den direkte dualisme, at man forsøgte at beskytte sig imod ondskaben ved at søge enklaven, også kaldet sekten, hvor man i et fællesskab med ligesindede kunne søge frelsen gennem askese. Askese i denne direkte dualistiske fase indebar træning og opøvelse af alt det, der konnoterede Gud og helliggørelse, for derigennem at få adgang til frelse.

I senmiddelalderen opstår der i jødedommen den tanke, at ondskaben opstod i denne verden som resultat af et uheld, en manglende evne hos Gud til at forudse svagheder i hans egen skabelsesstrategi og konsekvensen af disse svagheder. Udviklingen sker gradvist inden for kabbalismen, en jødisk mystisk retning, der udviklede sig fra 1100-tallet til 1600-tallet og medførte en forestilling om, at frelsen gik gennem et møde med ondskaben, en nedstigning til Farao, hvilket teknisk set fik betegnelsen 'Kom/gå til Farao'.

For at forstå den tanke om ondskabens oprindelse i en guddommelig fejl eller utilstrækkelighed, må man begynde med kabbalismens hovedværk, trebindsværket Sefer haZohar (bogen om den himmelske stråleglans). Zohar er en mystisk midrash, dvs. en aktualiserende udlægning, af Mosebøgerne, Ruts Bog og Højsangen. Zohar blev skrevet i slutningen af det 13. århundrede i en tid med messiansk nærforventning. I værket beskrives det, hvordan Gud ved hjælp af 10 sefirot (dvs. cifre, jf. de ti grundtal) og imellem dem 22 stier (jf. det hebræiske alfabets 22 bogstaver) ikke blot skabte verden, men bestandigt griber ind i verden. Sefirot kan siges at referere til Guds indgribende aspekter. Et af disse aspekter er dom, der associeres med sefirah'en Din ('dom'), der mildnes af Hesed ('nådig hengivenhed'), således at de tilsammen sikrer Guds retfærdighed. Hvis Din får magt uden at stå i relation til Hesed, dvs. fjerner sig fra sefirotsystemet, bliver den uforankrede Din til ondskab, forstået som fraværet af Guds omsorgsfulde grænsesætning. Bevidst synd provokerer denne splittelse i sefirot-systemet:

Syndere beskadiger den øvre verden, idet de forårsager en adskillelse mellem det 'Højre' [Hesed] og det 'Venstre' [Din]. ... [V]ed bevidst at klæbe til det onde adskiller man Nåde som guddommeligt aspekt fra Dom, det Højre fra det Venstre (Sefer haZohar II, 26b). ${ }^{3}$

I Zohar anses det som de særligt frommes opgave at engagere sig i at genforbinde sefirah'en Din med sefirot-systemet og således sikre, at Din balanceres af Hesed. Der står dog også allerede i Zohar, at et kendskab til både godt og ondt er en forudsætning for reparationsarbejdet: 'For mennesket bør have erkendelse om både godt og ondt og forvandle ondt til godt. Dette er et af troens dybe holdepunkter' (Sefer haZohar II,

2 Se ligeledes Jub 15,32-33; bSan 111b. For mere om Mastemas selvstændighed, se Koskenniemi 2005, 56-59

3 Alle oversættelser fra Zohar og den babylonske talmud er mine egne. 
34a). Er der ingen, der bidrager til dette reparationsarbejde, får ondskaben overtaget og herredømmet. Patriarken Abraham forstod, at Samael, en senere version af Mastema/Satan, der ofte portrætteres som en slange, havde magten over Farao pga. den løsrevne ondskab: 'Faraos herredømme havde sin oprindelse hos Slangen' (Sefer haZohar II, 27b). Under hungersnøden i Ægypten (Gen 12,10-20) drog Abraham derned for at forstå ondskaben. Hans formål var 'at undersøge disse andre dennesidige niveauer for at kunne vide, hvordan man skal undvige dem og forsage ægypternes levevis' (Sefer haZohar I, 80a). Pointen er med andre ord, at ved at lære ondskaben at kende kan den disciplineres. På lignende vis drog både Isak og Jakob ned til Ægypten. Senere, da Moses opfordredes til at 'komme/gå til Farao' i Exodus, umiddelbart for at bevidne hans forhærdelse, opnåede Moses den mystiske indsigt, at den ondskab, som Farao inkarnerede, har sit eget sefirot-system, der emanerer fra den uafbalancerede domfældelse (Sefer haZohar II, 34b). Det beskrives endvidere, hvordan også Farao er en reptil, nærmere bestemt en krokodille som Leviathan, der lever i de ægyptiske floder i overensstemmelse med tanken om et ondskabens sefirot-system, der har opnået midlertidig selvstændighed pga. menneskers synd og Dins efterfølgende løsrivelse fra det guddommelige sefirot-system (Tishby 1989, II: 455, 459).

Det er dog først ca. 250 år efter Zohars fremkomst, at ondskabens selvstændighed anføres som Guds og ikke længere menneskers skyld. I midten af det 16. århundrede havde diverse fordrivelser af jøder fra det meste af Syd- og Mellemeuropa medført en akut nærforventning blandt jøder, idet forfølgelserne blev opfattet som Messiasveer. Isak Luria (1534-1572), født i Jerusalem og grundlægger af luriansk kabbalah, studerede Zohar i sekluse, dvs. et rum afsondret fra ydre stimuli, i Ægypten i syv år, inden han slog sig ned i Safed i Galilæa, hvor han hurtigt blev leder af en lille kreds af kabbalister, der allerede holdt til i byen. Hans sekretær, Hayyim Vital, nedskrev Lurias belæringer i værket Etz Hayyim. Her beskrives, hvordan Gud planlagde skabelsen med et tænkt sefirot-system som skabelon, hvor hver sefirah skulle fungere som et kar, der skulle rumme elementer af Guds essens. Karrene var skabt vha. elementer fra Din, fordi det centrale ved domfældelse er afgrænsning, dvs. at gøre noget finit, hvilket er et kendetegn ved den immanente verden. På det tidspunkt i skabelsesprocessen, hvor Guds essens emaneredes ind i karrene, bristede de. Guds essens var så kraftfuld, at det ikke kunne rummes af de finitte kar. Guds essens spredtes ud i kosmos. Hvad værre var, sønderbrydelsen af karrene indebar også, at skårene fra karrene, der bestod af elementer fra Din, Guds domfældende indgriben, løsrev sig fra det begyndende aktualiserede sefirot-system, og deres løsrevne form blev til ondskabens skaller. Disse skaller voksede tilmed i styrke, fordi de i kosmos opsøgte rester af Guds essens, snyltede på den guddommelige essens' livskraft og omkapslede den, så skallerne fik selvstændighedstræk. Herefter måtte Gud påbegynde skabelsesarbejdet forfra og lærte af sin første fejl, idet han graduerede sin essens til gradvis svækkelse i takt med, at karrene emanerede og nærmede sig den immanente verden. Den praktiske konsekvens af denne myte, der benævnes den lurianske skabelsesmyte, blev en opfordring til alle jødiske mystikere til reparationsarbejde. Reparationsarbejde benævnes tikkun, og tikkun indebærer, at man skulle opsøge ondskabens skaller, som stadig er spredt ud i universet. Når guddommelig essens, indkapslet i ondskabens 
skaller, findes, skal essensen løftes ud af skallerne og tilbage til Gud i Guds mest transcendente format. Hermed forstår man også, hvorfor oversættelsen af ' $b o^{\prime}$ ' $æ l-$ par'oh som 'gå til Farao' ikke ville være fyldestgørende i senkabbalistisk kontekst. Ifølge mystikeren bør vendingen oversættes 'kom til Farao', fordi Gud kalder på Moses' og Israels folks hjælp inde fra Farao, hvor han er indespærret. Skal Gud hjælpes, må det ske gennem ondskaben, hvormed vi her bevidner et udtryk for inverteret dualisme.

\section{Shabbetai Tsvis 'fremmedartede handlinger' som tikkun}

Den shabbetaianske bevægelse er nok jødedommens mest radikale eksempel på inverteret dualisme. Bevægelsen har navn efter Messiasprætendenten Shabbetai Tsvi (1626-1676), der blev født i Smyrna, nutidens Izmir. Shabbetais far var en velstående handelsmand i Smyrna. Mens Shabbetais to brødre fulgte i faderens fodspor, viste Shabbetai evner for Torah- og Talmudstudier. Han fik sine første seks års religiøse skoling hos Isak di Alba, en lokal rabbiner, der var kendt for sin vægtning af pietistiske praksisser. Rabbinske studier fulgte, ligeledes i Smyrna, hos Josef Eskapha, en kendt fortolker af halakhah, dvs. bibelsk og rabbinsk lovstof, og det var igennem disse studier, at Shabbetai fik titel af hakham ('vis'), svarende til ordination som rabbiner i en ganske ung alder. Han valgte dog ikke at fungere som rabbiner, men afsondrede sig på asketisk vis, hvor han fordybede sig i traditionelle kabbalistiske værker, især Zohar. Hans frygt for ikke at kunne modstå seksuelle fristelser i denne periode bærer præg af Zohars opfattelse af, at Samael og Lilith, den hhv. mandlige og kvindelige repræsentant for ondskab, ville blive næret af sædafgang som følge af onani og seksuelle drømme. Som modtræk valgte han en asketisk livsstil, der indebar seksuel afholdenhed, ophold i sekluse, dvs. afsondrede rum, skriftstudier (gerne i naturen), rituelle bade i havet, spægelse af legemet og faste, typisk i løbet af ugens hverdage, således at han kun spiste på sabbatten. Som 20-årig blev han gift to gange. I begge tilfælde afstod han imidlertid fra at fuldbyrde ægteskabet ved samleje, og ægteskaberne blev hurtigt ophævet (Scholem 1973, 110-124; Halperin 2007, 3-4).

Det var allerede i forbindelse med Shabbetais tidlige asketiske livsstil, at han indledte sine ma'asim zarim, 'fremmedartede handlinger' - fremmedartede for jødedommen i den forstand, at de indebar overtrædelser af jødiske for- og påbud (Scholem 1973, 126-129). Overtrædelsen af budene forsvarede han dog med henvisning til Rabbi Nahman bar Yitzhaks talmudiske udsagn: 'stor er overtrædelsen, der sker for buddets egen skyld, frem for overholdensen, der ikke sker for buddets skyld' (bNazir 23b). At buddene kunne opfyldes på anden vis end ved bogstavelig udlægning, blev bestyrket ved, at Esajas havde profeteret, at en ny torah skulle udgå fra ham (Es 51,4). ${ }^{4}$ I Shabbetais samtid var der tilmed stærke nærforventninger til året 1648, idet man her forventede Messias' komme, hvilket samtidig indebar, at den nye torah, som bl.a.

4 Denne udlægning af Es 51,4 kræver et blik på den hebræiske originaltekst og associationer til jødisk mystiks komplekse opfattelse af Torah. Se nedenfor i denne artikel, og i øvrigt i Schleicher 2014. 
Esajas havde profeteret om, ville erstatte den gamle. De forventninger tilsammen legitimerede, hvad der for Smyrnas jødiske borgere fremstod som en synd, nemlig at Shabbetai ved oplæsning af Torah udtalte tetragrammet. Shabbetai selv mente dog, at han var i sin gode ret. Igen trak Shabbetai på Rabbi Nahman bar Yitzhak fra Talmud, der havde sagt:

Den kommende verden er ikke som denne verden. I denne verden skrives Guds navn med bogstaverne yod og heh, men udtales 'Adonai', som jo begynder med bogstaverne alef og dalet. Guds navn udtales ikke på samme måde, som det skrives. I den kommende verden vil alt imidlertid være sammenfaldende: Guds navn vil både læses ud fra yod og heh og skrives med bogstaverne yod og heh (bPes 50a).

At Shabbetai var sikker på, at den kommende verden var indtrådt skyldtes, at han også i 1648 fik en audition, hvor Gud udvalgte ham til Messias. Udvælgelsen efterfulgtes af en vision, hvor patriarkerne salvede ham. For Shabbetai var udtalelsen af tetragrammet således konsistent med talmudisk, messiansk teologi. Smyrnas rabbinerkollegium under ledelse af Shabbetais tidligere læremester Josef Eskepha betragtede det imidlertid som en budovertrædelse og ekskommunikere ham fra Smyrna (Scholem 1973, 136-142; 149-151).

Den næste 'fremmedartede handling' fandt sted i Salonika, hvor Shabbetai slog sig ned efter sin første ekskommunikation. Som supplement til sin fortsatte udtalelse af tetragrammet inviterede han byens prominente rabbinere til at overvære sit eget bryllup med en torahrulle. Denne 'fremmedartede handling' forargede Salonikas rabbinere, så Shabbetai ligeledes blev ekskommunikeret fra denne by (Scholem 1973, 158159). Salonikas rabbinere delte næppe Shabbetais messiansk-mystiske referenceramme, hvor Guds immanente tilstedeværelse i form af den nederste sefirah Shekhinah i sefirot-systemet ved det messianske riges fremkomst vil være den brud, som Israels folk skal forenes med i et hieros gamos, dvs. helligt ægteskab. Fordi torahstudier i sidste ende skal afstedkomme dette hieros gamos og dermed den messianske tidsalder, er denne 'fremmedartede' omgang med Torah således i god overensstemmelse med Torahs overordnede mål, jf. ovenfor om bNazir 23b.

Efter nogle års vandring gennem Grækenland kom Shabbetai i 1658 til Konstantinopel (nutidens Istanbul). Her svøbte han en stor fisk som et spædbarn og lagde den $i$ en vugge som tegn på, at Israels forløsning skulle ske i fiskens stjernetegn. Endvidere fejrede Shabbetai de tre pilgrimsfester (påsken, ugefesten og løvhyttefesten) på én dag i håb om, at en sådan koncentration af hellig tid kunne bidrage til at sone alle Israels synder på én gang. Hvad angik udtalelse af tetragrammet, blev det nu suppleret med udtalelse af andre gudsnavne, som Shabbetai havde kendskab til fra især Abraham Abulafias kabbalah fra det 13. århundrede, hvor ekstatiske teknikker muliggjorde mystikeres oplevelse af at blive forenet med Gud. Shabbetai holdt sågar studiekredse, hvor han sammen med sin begyndende discipelkreds studerede Abalufias tekster og praksisser (Idel 1998, 185-187. 198-199). Af frygt for, at Shabbetai skulle få held til at tiltrække sig flere disciple og danne en egentlig sekt, idømte Konstantinopels rabbinere Shabbetai 40 piskeslag, sandsynligvis en periode med fængsling, og herpå endnu en ekskommunikation, hvorpå han vendte tilbage til sin fødeby Smyrna og forblev der frem til 1662 (Scholem 1973, 160-165. 171). 
I håb om, at en pilgrimsfærd til Jerusalem kunne kurere Shabbetai for den maniodepressivitet, der havde plaget ham siden ungdommen, opfordrede hans brødre ham til at drage til jødedommens helligste by. Shabbetais rejse dertil bragte ham bl.a. forbi Kairo, hvor han etablerede et venskab med de ægyptiske jøders leder, Raphael Joseph. Raphael Joseph var kendt for sin ekstreme askese, herunder spægelse af legemet, nattevågen, rituelle bade og spartansk påklædning, hvilket harmonerede med Shabbetais asketiske praksisser (Scholem 1973, 177-178). I Jerusalem opholdt Shabbetai sig fra 1662 til 1663 i den jødiske bydel, hvor han erhvervede sig en ejendom, hvor et rum blev sat til side som sekluse. I seklusen studerede han i ugens løb. Han spiste kun på sabbatter og begav sig ud på lange ørkenvandringer. I denne periode er der kilder, der indikerer, at Shabbetai også blev idømt piskestraf for sine 'fremmedartede handlinger' af Jerusalems rabbinske ledelse. Det stod dog ikke i vejen for, at Shabbetai, måske pga. sin økonomiske uafhængighed, asketiske livsstil og gode forhold til Raphael Joseph, blev sendt til Ægypten for at indsamle midler til den jødiske menighed i Jerusalem, fordi osmannerne havde lagt et hårdt skattetryk på byens jødiske borgere. Ophold og bøn ved grave begynder fra denne del af Shabbetais liv at indgå som en vigtig praksis, og inden afrejse til Ægypten fra det hellige land besøgte Shabbetai patriarkernes grav i Hebron, græd under bøn ved graven, fastede under sit ophold i Hebron og reciterede salmer om natten på ekstatisk vis. Hans indsamlingsmission lykkedes, og i 1664 kunne Shabbetai overbringe Jerusalems jøder en betragtelig sum på 3-4000 løvensdaler (Scholem 1973, 180-188; 198).

På sin indsamlingsmission i Ægypten fra 1663 til 1664 udførte Shabbetai en ny 'fremmedartet handling'. Shabbetai giftede sig med Sarah, der var af polsk-jødisk oprindelse. Et giftermål er ikke nødvendigvis underligt; men det, der gjorde denne handling 'fremmedartet', var, at Sarah efter sigende havde en fortid som prostitueret, og at Sarah også skulle have udført 'fremmedartede handlinger', herunder proklameret, at hun skulle giftes med Messias. Flere religiøse motiver udledt af hendes livshistorie kan ligge bag giftermålet. I 1648-1649 angreb ortodoks-kristne bønder og kosakker i det polsk kontrollerede Ukraine landets polakker, katolikker og jøder. Det resulterede i en omfattende massakre, der refereres til som Chmielnicki-massakren, der har navn efter lederen af de angribende styrker, den ortodoks-kristne Bogdan Chmielnicki. Ca. 350.000 døde, heraf ca. 100.000 jøder, hvilket historisk set gjorde den til den mest omfattende massakre på jøder nogensinde på daværende tidspunkt. Sarah, der var datter af den polsk-jødiske rabbiner Meir, mistede sine forældre under massakren. Sarah selv havde held til at flygte og fandt beskyttelse i et katolsk nonnekloster, hvor hun mere eller mindre frivilligt konverterede til kristendommen. Sarahs afdøde far kom dog efter ti år til Sarah i en vision og bevirkede, at hun på magisk vis blev teleporteret til en jødisk begravelsesplads, hvor far og datter så kunne have en samtale. Faderen fortalte hende, at hun havde en bror i Amsterdam, der ville kunne hjælpe hende. Sarah rejste til Amsterdam; men broderen fandt hun ikke. Hun ernærede sig da som prostitueret og spåkone i Amsterdam og senere i Italien. Shabbetai vidste, at Messias ifølge profeten Hosea skulle giftes med en horkvinde (Hos 1,2). Udover således at passe ind i en af traditionel jødedoms centrale profetier, kunne Sarahs askenasiske oprindelse og erfaring med Chmielnicki-massakren samt hendes 
migrationsrute gennem askenasisk territorium fra Polen over Holland, inden hun nåede Mellemøsten, have stor betydning dels for Shabbetai i forhold til at se det guddommelige i den ellers så katastrofale Chmielnicki-massakre, dels for at inkludere de askenasiske jøder i den shabbetaianske bevægelse. Under bryllupsnatten fuldbyrdede Shabbetai for første gang et samleje; men lagenet bekræftede efter sigende også, at Sarah trods beskyldninger om hor hele tiden havde været jomfru (Radensky 1997, 47-50; Scholem 1973, 196-197; 413).

I 1665 opsøgte Shabbetai Abraham Nathan ben Elisha Hayyim Ashkenazi, der senere blev kendt som Nathan fra Gaza. Nathan var født og opvokset i Jerusalem. Hans far var pengeindsamler i Europa og Nordafrika for de jerusalemittiske jøder og samtidig kendt som udgiver af luriansk-kabbalistiske tekster. Nathan havde fået sin videregående rabbinske uddannelse på en hesger, som er det tætteste man i jødedommen kommer på et kloster. Ordret betyder hesger aflukke og antyder, parallelt med ordet kloster i kristendommen, graden af seklusion og askese, der forventedes af de Talmud-studerende, der var blevet optaget på institutionen (Scholem 1973, 249). Efter endte studier ved denne hesger blev Nathan 'gift væk' til en jødisk rigsmands datter i Gaza, sådan som det skete for fattige, men begavede rabbineruddannede. De nygifte boede hos datterens familie og var således sikret underhold, ligesom Nathans fortsatte studier på egen hånd var finansieret (Scholem 1973, 200-202).

For Nathan indebar voksenlivet en kabblistisk vækkelse, hvor det især var Sefer haZohar og et bredt udsnit af centrale lurianske tekster, som han i modsætning til Shabbetai satte sig ind i. Disse kontemplative studier blev koblet med seksuel afholdenhed, spægelse af legemet, faste og sekluse. Nathan tiltrak sig mange tilhængere, der kom til ham for at bruge ham som sjælesørger og for at få anvist tikkunim, dvs. praksisser, som de skulle udføre for at sone deres sjæle og løfte dem ud af ondskabens skaller, jf. ovenfor om den lurianske skabelsesmyte. Typisk foreskrev han dem faste og spægelse af legemet. Gud kaldte endvidere Nathan til profet for Shabbetai i en række natlige drømme med dertilhørende visioner (Scholem 1973, 206-207). Til trods for Nathans kaldelse til Shabbetais profet var det faktisk Shabbetai, der havde hørt rygter om Nathans aktivitet, og som derfor opsøgte ham i foråret $1665 \mathrm{i}$ håb om, at Nathan kunne foreskrive ham en lindrende tikkun for hans sjæl, der var forpint af depression. Nathan og Shabbetai tilbragte adskillige uger sammen, og den 31. maj 1665 proklamerer Shabbetai nu offentligt, at han var Messias, med støtte fra den teologisk stærkere Nathan.

I anledning af denne offentliggørelse fik Shabbetai fremstillet tre ringe. På den første ring var indgraveret tetragrammet, på den anden en numerologisk ækvivalent for gudsnavnet Shaddai ('den almægtige'), og på den tredje ring var ingen tekst indgraveret, men sandsynligvis et billede af den krogede, hellige slange, hvor 'hellig slange' på hebræisk er en numerologisk ækvivalent for Messias. Den første store Shabbetai Tsvi-forsker, Gershom Scholem, mener, at slangebilledet fungerede som signatur, dvs. den tredje ring var Shabbetais signetring. Sammenstillingen af de tre ringe markerede således Shabbetais rolle som Messias og måske endda som Gud (Scholem 1973, 234-236). Udvidelsen af rollen fra Messias til Gud kan forklares med henvisning 
til Abulafias ekstatiske kabbalah, der foreskrev praksisser, hvormed man kunne aktivere den del af intellektet, der var guddommeligt. Gennem denne aktivering blev man så forbundet med Gud, at man også til tider kunne tale om sig selv som Gud. Denne vovede opfattelse, at man med afsæt i en aktivering af ens eget guddommelige intellekt blev Gud, blev hos Shabbetai og Nathan endvidere koblet med den lurianske skabelsesmyte, hvor man skulle udfri de guddommelige gnister fra ondskabens omklamrende skaller. Med andre ord er Shabbetai, når Shabbetai er Gud, der samtidig skal udfri de guddommelige gnister, blevet et eksempel på fænomenet salvator salva$n d u s$ (frelseren der skal frelses). Shabbetais disciple refererede derfor til Shabbetai som AMIRAH, et akronym for 'Vor Herre og konge, ophøjet være hans majestæt' (hebr: Adoneinu Malkeinu YaRum Hodo), hvorved de bekendte deres tro på både hans messianske og guddommelige identitet (Scholem 1973, 262-263; Idel 1998, 199-205).

Også i 1665 udvalgte Shabbetai tolv af Gazas mest lærte rabbinere som repræsentanter for Israels tolv stammer med henblik på at drage til Jerusalem for at ofre på Tempelbjerget inde i Omarmoskeen. Følget opgav dog offerhandlingen i Omarmoskeen, da de nåede frem og nøjedes med at circumambulere Jerusalem syv gange på hesteryg til trods for, at osmannerne havde forbudt jøder at ride til hests. Shabbetai havde dog ansøgt om og fået dispensation. Shabbetai var iført grønne gevandter, der i islamisk tradition - og måske blandt Jerusalems jødiske borgere - kunne opfattes som en klar reference til indvarslingen af den messianske tidsalder (Scholem 1973, 210-223. 240-242). Under opholdet i Jerusalem fik han repræsentanterne for de ti forsvundne stammer til at spise fedt fra offerdyrets nyrer, hvilket ellers var forbeholdt Jahve, jf. fx Lev 3,1-5. Hvad der er desto mere interessant er, at Shabbetai nu udtalte følgende antinomiske velsignelse: 'Velsignet være du, oh Herre, der tillader det, som er forbudt', sågar efterfulgt med en opfordring til hans tilhængere om også at spise offerdyrsfedt. For Jerusalems borgere og rabbinske ledelse fremstod dette indtog og indtagelse af offerdyrsfedtet som overtrædelser. Det resulterede i, at han i $1665 \mathrm{blev}$ ekskommunikeret og udvist fra Jerusalem for anden gang. Nogle kilder hævder endda, at Jerusalems rabbinske ledelse udstedte et 'fatwa', der bestemte, at shabbetaiansk forkyndelse betragtedes som kættersk, og at den, der dræbte forkynderen, gjorde sig fortjent til Guds velsignelse, fordi han således indirekte ville frelse mange sjæle (Scholem 1973, 142-143. 248-249). Ekskommunikation og fatwa bed dog ikke på den antinomiske duo. Bevæbnet med den lurianske skabelsesmyte blev enhver 'fremmedartet handling' udlagt som udtryk for Shabbetais kamp mod den store drage med det formål at 'udlede stor hellighed fra kelippot', dvs. ondskabens skaller (Nathan, Dragetraktaten 39, citeret efter Scholem 1973, 131).

Nathan bidrog også til at forklare Shabbetais antinomiske tilgang til Torah. Torahs betydning var for så vidt allerede stærkt relativeret i jødedommen, først med Talmuds opfattelse af Torahs 70 ansigter og senere med den lurianske kabbalahs forklaring, at fordi den skriftlige torah blev formidlet til 600.000 israelitter, var den blevet skabt med 600.000 bogstaver. Hver jøde, der er efterkommer af en af disse israelitter, deler en sjælerod med forfaderen og er således forbundet gennem sjæleroden til et særligt betydningsaspekt ved den skriftlige torah, der vil fremstå klart ved den messianske forløsning. Med Messias' komme vil den skriftlige torah dermed afsløre sine 
600.000 betydninger, om end man kun vil få indblik i den betydning, der er møntet på éns egen sjælerod (Scholem 1956, 74-76). Betydningsrelativismen og især tanken om en personlig torah muliggjorde Shabbetais antinomiske tilgang. Nathan koblede den lurianske opfattelse med det tidligere kabbalistiske værk, Sefer haTemunah (ca. 1250), ifølge hvilken hver tidsalder har sin Torah. Hver tidsalder var præget af et af Guds indgribende aspekter. I tidsalderen før den nuværende var skabelsen frembragt af Guds barmhjertighed. Dette var en ideel urtid, hvor alt fremstod i harmoni. Den nuværende tidsalder er imidlertid genereret af Guds dømmende aspekter, hvor Moses' Torah, dvs. de fem Mosebøger, skal korrigere for menneskers synd. Moses' torah vedrører derfor primært den materielle eksistens og fokuserer på at sætte grænser for adfærd og livsopfattelser. Den kommende tidsalder ville imidlertid ophæve alle de forbud, der er specificeret i Mosebøgerne for den nuværende tidsalder, ligesom det forventedes, at Torahs åndelige indhold ville træde frem, mens den praktiske udførelse af budene i materialiteten ville blive overflødiggjort (Scholem 1956, 92; 1973, 319321; Halperin 2007, 19). ${ }^{5}$

I dette inverterede lys giver det mening, at Shabbetai i december 1665, tilbage i Smyrna, under en sabbatsgudstjeneste tog en torahrulle ud af torahskabet under synagogegudstjenesten og sang den spanske romance "Meliselda" til Torahrullen, som var den Shekhinah, Guds mest immanente aspekt, der tit skildres som en brud. Han læste derpå op fra et trykt kodeks med Mosebøgerne og hævdede, at kodekset var mere helligt end håndskrevne Mosebøger på rulle. Herpå samlede han sine hænder om munden og trompeterede i retning af de fire verdenshjørner, som var det det jødiske nytår, hvor Satan skulle forvirres og kelippots magt konfronteres ved hjælp af shofarblæsning. Han krævede endvidere, at ikke kun mænd, men også kvinder læste op fra kodeksudgaven og ikke fra torahrullen, samt at de udtalte tetragrammet (Scholem 1973, 395-401. 427-430).

Stemningen i Smyrna blev så anspændt på grund af disse liturgiske omkalfatringer, at Shabbetai forlod sin fødeby og sejlede til Konstantinopel den 30. december 1665. Flere af Shabbetais tilhængere og måske også han selv forbandt destinationen med en forventning om, at Shabbetai uden blodsudgydelse ville overtale sultanen over Osmannerriget Mehmet IV til at overdrage den jordiske regeringsmagt til sig (Halperin 2007, 9). Smyrnas rabbinske ledelse advarede kollegerne i Osmannerrigets hovedstad, og da Shabbetai efter en del uvejr undervejs ankom til Konstantinopel den 8. februar 1666, blev han på storvesirens arrestordre anholdt, sandsynligvis af frygt for, at byens jødisk ledede handelsliv ville gå i stå, og at jødiske mænd ville lade deres familier uforsørgede tilbage for at følge Shabbetai, sådan som det var sket $\mathrm{i}$ andre byer med mange shabbetaianske tilhængere (Scholem 1973, 432-434. 445-449). Shabbetai blev fængslet; men efter nogle få uger i et almindeligt fangehul blev Shabbetai overført til en form for luksuriøs husarrest. Han tolkede selv sin fængsling som et nødvendigt ophold blandt kelippot i Ægypten (Scholem 1973, 453-456). Under påsken dette år ofrede han i husarresten et påskelam og spiste offerfedtet, ligesom han bød de jøder, der var fulgt med ham i husarrest, at indtage offerfedtet, idet han udsagde

\footnotetext{
Afsnittet om Shabbetais syn på Torah er en forkortet version af min præsentation i Schleicher 2014.
} 
den antinomiske velsignelse: 'Velsignet være du, oh Gud, som tillader det, der er forbudt' (Scholem 1973, 458-460).

Endnu en fremmed handling var, at Shabbetai i sommeren 1666 efter sin mors død beordrede sine tilhængeres bøn ved hendes grav i Smyrna. Tog man en sådan pilgrimsfærd til graven på sig og gennemførte man et rituelt bad i en nærved liggende kilde, ville man få syndsforladelse. Lagde man en hånd på hendes grav, fik man tilmed fortjeneste, som havde man foretaget en pilgrimsfærd til Jerusalem. Shabbetai forbød i samme periode fra husarresten sine tilhængere at holde husdyr så som hund og kat pga. deres urenhed, da det kunne forårsage, at Messias blev væk. Ligeledes skulle tilhængerne holde alle deres hebræisk-sprogede bøger åbne, således at Messias kunne genkende deres jødiske identitet (Scholem 1973, 110. 613-614). De tilhængere, der besøgte ham i husarresten, modtog typisk helbredende stykker mad, klædning eller anden form for relikvie med dertilhørende velsignelse, der indikerede, at Shabbetai ville sørge for den besøgendes genopstandelse til et liv i den messianske tidsalder. Tilhængernes stræben efter syndsbekendelse medførte nye ekstreme praksisser, herunder bøn i begravede tilstande, hvor kun hovedet stak op over jorden, symbolske gennemførelser af en af de fire rabbinske former for dødsstraf (stening, brænding, halshugning og kvælning), mellem 700 og 800 børneægteskaber med dertilhørende sex med mindreårige, og ellers ekstrem askese i en sådan grad, at flere shabbetaianere døde (Scholem 1973, 625-626. 633-634).

De tyrkiske myndigheder ændrede syn på Shabbetai, da hans intensiverede inverterede dualisme fik uhensigtsmæssige konsekvenser for ro og orden i riget. For det første resulterede Shabbetais antinomiske handlinger i voldelige konfrontationer mellem tilhængere og ikke-overbeviste jøder. For det andet hævdedes det, at alskens utugt var opstået efter, at Sarah havde fået lov til at opholde sig sammen med Shabbetai i husarresten. Blandt andet skulle de have etableret et harem, og Shabbetai skulle have haft samleje med et utal af jomfruer, dog uden at deflorere dem. For det tredje begyndte dervisher af sufi-observans og andre muslimer at slutte op om Shabbetai (Scholem 1973, 629-632. 670-671). Den 12. september stævnede de osmanniske myndigheder derfor Shabbetai og deporterede ham til sultanens residens i Adrianopel (nutidens Edirne).

Nathan forsøgte at dæmme op for tilhængernes fortvivlelse ved at forklare, at det var i Shabbetais interesse at møde sultanen, idet Shabbetai ønskede at overtage tronen fra sultanen, lade denne blive Shabbetais slave, benytte sultanens hær til at bekæmpe de hedninge, der var skyld i Chmielniski-massakren, indsamle de eksilerede og således forløse Israels folk (Liebes 1993, 95-96). Sultanen så imidlertid højst på gennem et slør, som det var sædvane under kabinetsmøder. Shabbetai mødtes ikke med sultanen, men i stedet med nogle af landets højtstående embedsmænd. Kildematerialet om, hvad der skete, er tvivlsomt, og det eneste man synes at vide er, at Shabbetai ikke insisterede på nogen form for Messiasidentitet over for de tilstedeværende, og at han, da han blev konfronteret med valget mellem død og konversion, valgte at konvertere til islam. Konversionen fandt således sted den 16. september 1666. Det er uvist, om Shabbetai allerede under mødet med embedsmændene tænkte en sådan konversion som en 'fremmed handling' eller om det egentlig var Nathan, der bidrog til denne 
udlægning senere. I hvert fald accepterede Shabbetai konversionen, fik det nye navn Aziz Mehemed Effendi efter Sultan Mehmed IV, blev givet en hvid turban, en ekstravagant klædedragt og fik sågar en stilling som vogter af sultanens paladsporte. Nogle dage senere konverterede Sarah også, hvilket var hendes anden konversion, idet hun som barn jo var blevet tvangskonverteret til kristendommen. Endelig konverterede som nævnt i indledningen en mindre skare på 2-300 jødiske familier, der grundlagde Dönmeh-sekten. Blandt dem var en del conversos, dvs. jøder, der på den iberiske halvø var blevet tvangskonverteret til kristendommen, men som havde fastholdt en jødisk praksis indadtil uden kommunikation med rabbinske autoriteter. Disse conversos havde derfor et andet forhold til en ydre konversion, denne gang til islam, end jøder, der historisk set havde kunnet fastholde deres jødiske identitet offentligt (Lewis \& Roth 1963, 221; Scholem 1973, 673-684; Idel 1998, 184).

Fra konversionen i 1666 og de sidste ti år af Shabbetais liv forstummede furoren om ham til en vis grad. Shabbetai, Nathan og den nu reducerede tilhængerskare engagerede sig $\mathrm{i}$ at forklare konversionen. Shabbetai skrev selv et brev ud til tilhængerne om, at Gud havde befalet ham konversionen, og især Nathan inddrog Zohar og luriansk kabbalah i et forsøg på at udlægge det som et eksempel på at 'gå/komme til Farao', hvormed Shabbetai kunne udfri de guddommelige indespærrede gnister ud af ondskabens skaller blandt medomskårne. De osmanniske myndigheder løslod Shabbetai, men sendte ham langt væk fra imperiets centrum til Dulcigno (nutidens Ulcinj) i Montenegro, hvor han også døde, og hvortil pilgrimme er valfartet frem til begyndelsen af det 20. århundrede (Liebes 1993, 96. 111; Halperin 2007, 17; Wolfson 1998, 256).

\section{Konklusion}

Shabbetais udtalelser af tetragrammet og andre gudsnavne, bryllup med en torahrulle, ufuldbyrdede ægteskaber med ærbare jomfruer, men fuldbyrdet ægteskab med en prostitueret, spædbarnspleje af en fisk, liturgiske omkalfatringer af højtider, sabbatter, velsignelser og bønner, udpræget 'tantrisme' med grave som bedesteder, sågar nedgravning som udgangspunkter for bøn, ritualiseret gennemlevelse af de fire bibelske dødsstrafformer, ekstrem askese med faste, seklusion og spægelse af legemet, for nogle tilhængere med døden til følge, tilhængernes akutte masseindgåelse af børneægteskaber og endelig egen og nogle tilhængeres konversion til islam, råber på forklaringer, der tager den religionshistoriske udvikling i betragtning.

Man ved, at Shabbetai Tsvi såvel som hans profet Nathan af Gaza var vel skolet og belæst i rabbinsk og mystisk litteratur såvel som undervist og erfarne i asketiske praksisformer. Teologisk set var både teosofisk og eksatisk kabbalah referenceramme for Shabbetai Tsvi, ligesom Nathan af Gaza med sin indsigt i luriansk kabbalah og flair for systematisk teologisk tænkning kunne tilføje et legitimeringsgrundlag for Shabbetais 'fremmedartede handlinger' på en måde, som var konsistent med kabbalismens udvikling i retning af, hvad jeg her kalder inverteret dualisme. 
Begrebet 'inverteret dualisme' har jeg afledt af de teoretiske elementer, der er nævnt i indledningen, hvor analogistisk ontologis udvikling i nogle religionshistoriske tilfælde resulterer $\mathrm{i}$, at forløsningsveje må findes gennem urenhed, synd og død, sådan som man kender det $\mathrm{fx}$ fra den tantriske begravelsespladsaskese. Den inverterede dualisme, hvor ondskaben må opsøges som en forudsætning for frelse, præsenteres så vidt vides første gang i Sefer haZohar, hvor patriarkerne og Moses fremhæves for at have konfronteret ondskaben på ondskabens domæne og for at have lært den at kende med henblik på at besejre den. Konfrontationen forbindes med udtrykket 'komme/gå til Farao', der bliver en teknisk term for mystiske praksisser, der indebærer interaktion med det onde, det syndige og/eller døden. Da man tilmed i luriansk kabbalah antager, at ondskabens skaller har indkapslet guddommelig essens, hvor udfrielse af det guddommelige bliver en forudsætning for den messianske tidsalders indtræden, bliver det enhver mystikers pligt at engagere sig i mødet med alt, hvad der er forskelligt fra Gud. Denne verden i al sin immanens dækker også over den guddommelige verden, hvorfor skepsis rettes mod Torah, hvis umiddelbare betydning udlægges som enten et nødvendigt første lag eller som noget, der kan annulleres. Med andre ord kan inverteret dualisme forklare Shabbetais 'fremmedartede handlinger'. Konversionen til islam var for radikal for flertallet af jøder. Ifølge Shabbetais og Nathans opfattelse var det imidlertid blot et forsøg på at udfri den guddommelige kerne i islam og dermed sikre de medomskårne, abrahamittiske brødres adgang til frelse.

Et spørgsmål, som jeg ikke kan besvare her, men som rejser sig som perspektiv ved denne gennemgang af et jødisk eksempel på inverteret dualisme er, om inversionen medfører det kollaps af dualisme, som vi ser hos Shabbetai Tsvis samtidige, Marrano-jøden Baruch Spinoza. Bl.a. David J. Halperin har på baggrund af sit brede kendskab til jødisk religionshistorie hæftet sig ved Spinozas immanentistiske tænkning, der bl.a. blev præsenteret i 1670 i Tractatus Theologico-Politicus, og hvor han i samme ånd gjorde op med jødisk rigoristisk praksis og udlægning af jødedommens helligtekster. Halperin forklarer dog sammenfaldet alene med henvisning til, at de historiske levevilkår fordrede en ny udgave af jødedommen (Halperin 2007, 17). Andre har peget på, at det er slående, at reformjødedommen halvanden hundrede år senere, hvor hver enkelt med sin fornuft skal sortere i budene, der ikke længere betragtes som guddommelige, fik sine første og mest engagerede tilhængere blandt desillusionerede shabbetaianere, frankister og Marrano-jøder. Disse 'blakkede' tilhængere havde mere eller mindre tvungne konversioner til islam og kristendom til fælles, ligesom de uden adgang til rabbinske autoriteter på hemmelig vis havde videreført en jødisk praksis i hjemmene på baggrund af deres egne vurderinger af, hvad der var helliggørende. Måske er den inverterede dualisme med afslutningsvist kollaps forudsætningen for at forstå vor tids posthumanistiske udgangspunkt i immanentisme og semi-animistiske ontologier, sådan som det eksempelvis ses hos Gilles Deleuze (1998), Philippe Descola (2013, 68-69. 79-80), Bruno Latour (2008) og Rosi Braidotti (2013, 85-86), hvor Spinoza ofte henvises til som inspiration. 


\section{LITTERATUR}

Bellah, Robert N.

1964 "Religious Evolution", American Sociological Review, 29 (3), 358-374. https://doi.org/10.2307/2091480

Braidotti, Rosi

2013 The Posthuman, Cambridge: Polity Press.

Deleuze, Gilles

1988 Spinoza: Practical Philosophy, San Francisco: City Lights Books.

Descola, Philippe

2013 Beyond Nature and Culture, University Press of Chicago. https://doi.org/10.7208/chicago/9780226145006.001.0001

Halperin, David J.

2007 Sabbatai Zevi - Testimonies to a Fallen Messiah, Oxford: Littman Library.

Idel, Moshe

1998 Messianic Mystics, Yale University Press.

Koskenniemi, Erkki

2005 The Old Testament Miracle-workers in Early Judaism. Tübingen: Mohr Siebeck.

Latour, Bruno

2008 What is the Style of Matters of Concern? Two Lectures in Empirical Philosophy. Spinoza Lectures at the University of Amsterdam, Amsterdam: Van Gorcum.

Lewis, Geoffrey L. \& Cecil Roth

1963 "New Light on the Apostasy of Sabbatai Zevi", Jewish Quarterly Review 53 (3), 219-225. https://doi.org/10.2307/1453747

Lundager Jensen, Hans Jørgen

2017 "Om gammeltestamentlig og tidlig-kristen ontologi: kosmologi, topologi, teologi, thanatologi", Notat til undervisningen $i$ Israelitisk religion (12 sider).

Liebes, Yehudah

1993 Studies in Jewish Myth and Jewish Messianism, Albany: SUNY Press.

Radensky, Paul Ira

1997 "Leyb Ben Ozer's 'Beshraybung Fun Shabsai Tsvi': An Ashkeniz Appropriation of Sabbatianism", Jewish Quarterly Review, 88 (1-2), 43-56. https://doi.org/10.2307/1455062

Schleicher, Marianne

2014 "Præeksistent torah", Forum for Bibelsk Eksegese, nr. 18, 115-138.

Scholem, Gershom

1956 "The Meaning of the Torah in Jewish Mysticism", Diogenes, Vol. 4, No. 36. https://doi.org/10.1177/039219215600401403

1973 Sabbatai Sevi - The Mystical Messiah, Princeton University Press.

Tishby, Isaiah

1989 The Wisdom of the Zohar: An Anthology of Texts, 3 Volumes, London: Littman Library.

Wolfson, Elliot R.

1998 "The Engenderment of Messianic Politics: Symbolic Significance of Sabbatai Sevi's Coronation", in: Peter Schäfer \& Mark R. Cohen, eds., Toward the Millenium: Messianic Expactations from the Bible to Waco, Leiden: Brill, 203-258.

Marianne Schleicher, lektor, ph.d. Afdeling for Religionsvidenskab, Aarhus Universitet ms@cas.au.dk 